\title{
ENTREPRENEURSHIP AS AN EDUCATION- PROFESSIONAL PATHWAY DIRECTION FOR PROFESSIONAL (VOCATIONAL) EDUCATION SCHOOLS STUDENTS
}

\author{
Dmytro Zakatnov, \\ $\mathrm{PhD}$ in pedagogics, senior researcher, Head of the Laboratory for professional life Institute of vocational education and \\ training of NAES of Ukraine \\ http://orcid.org/0000-0002-4130-089X \\ e-mail:23dazkum@ukr.net
}

\begin{abstract}
Abstarct. The article reveals the state-of arts of the problem on professional (vocational) education $(\mathrm{P}(\mathrm{V}) \mathrm{E})$ schools students training to choosing the entrepreneurship activity as the way for further professional career development. It is found that the entrepreneurship activity content in the legislation framework of Ukraine is limited with acts jure gestionis aimed at reaching the economy and social results and profit. That differs from the appropriate content in the EU countries where the entrepreneurship is defined as the ability to plan and manage projects with have cultural, social or commercial value. The analysis the pilot research empirical data and the experimental activity of the Institute of vocational education and training of the National academy of educational science of Ukraine (IVET NAES of Ukraine) proves that $\mathrm{P}(\mathrm{V}) \mathrm{E}$ schools students consider the entrepreneurship activity as a prospective vector for further education-professional rout realisation due to some indicators difference for urban and rural $\mathrm{P}(\mathrm{V}) \mathrm{E}$ schools students. Therefore, the students' vision of the entrepreneurship activity is mostly of abstract character but their training to that in $\mathrm{P}(\mathrm{V}) \mathrm{E}$ schools is provided only for some aspects. The entrepreneurship activity socio-economic value and attractiveness for the youth as a prospective vector for their education-professional routs are determined with the appropriate pedagogical system formation to assure students' preparation for the entrepreneurship activity.

Conforming to modern education paradigm it should be the competence-based system to assure the entrepreneurship competence forming for $(\mathrm{P}(\mathrm{V}) \mathrm{E})$ schools students as their sustainable, integral and personal de novo synthesis. Main requirements to structure of that kind are defined and the scope of problems is outlined. Dealing the following factors will promote the quality increase on $\mathrm{P}(\mathrm{V}) \mathrm{E}$ schools students training for the entrepreneurship activity.
\end{abstract}

Keywords: entrepreneur, entrepreneurship activity, system of preparation for entrepreneurship, educationalprofessional rout, professional (vocational) education.

Introduction. Changes in the socioeconomic life of Ukraine testify to the irreversible transition to market conditions of economic activity, where one of the most significant features is entrepreneurship development as competitive economy basis. In this approach, further development of the state directly depends on the young people's willingness and ability to engage in entrepreneurial activity, that is, the youth preparation for entrepreneurship becomes a category of publicstate significance, since its quality depends on both the economic market transformations success and the domestic economy efficient functioning. The need for the youth training in entrepreneurship in VET process of vocational education is emphasized in a number of international documents, for example - Action plan for implementing the Strategy for technical and vocational education and training for 2016-2021 (UNESCO, 2016) It defines the need for its transformations and increasing attractiveness as a vector for the youth employment and entrepreneurship 
development. Under this approach, the problem of preparing students of professional (vocational) education $(\mathrm{P}(\mathrm{V}) \mathrm{E})$ institutions to choose the entrepreneurial activities as a way of their further educational and professional realisation is a topical socio-pedagogical problem.

Materials and methods. The psycho-pedagogical aspects of students preparing to choosing the entrepreneurial activity as a professional line are covered in the works of O. Padalka, N. Pobirchenko, I. Prokopenko, I. Sasova, V. Drzhak, D. Zakatnova, N. Pasichnyk, M. Tyemenko, O. Topol and other researchers. The peculiarities of entrepreneurship training in vocational education institutions are disclosed in the publications of O. Bogonis, L. Kozachok, G. Matukova, V. Tkachenko and others. However, problems related to the training $\mathrm{P}(\mathrm{V}) \mathrm{E}$ students for further entrepreneurial activity, as well as their preparation for choosing the entrepreneurship as a direction for the implementation the promising educational-professional routs, are not adequately covered.

The research aim is based on the experimental work empirical data analysis to find out the state-ofarts of the problem on $\mathrm{P}(\mathrm{V}) \mathrm{E}$ students preparing to choose the entrepreneurship as a vector for educationalprofessional rout development.

Results and discussions. The article 42 of the Commercial Code of Ukraine defines the entrepreneurship as an independent, initiative, systematic, at its own risk, economic activity carried out by economic entities (entrepreneurs) in order to achieve economic and social results and profit. Although the entrepreneurial activity is related to social needs satisfaction, however, its main motive is the material interest - profit. Under this approach, an entrepreneur is a person who has: financial and other resources, a business inclination, ideas about business organization and the ability to take responsibility for the risk while setting up a new enterprise, the development of a new idea, product or type of service. The successful implementation of business involves not only relevant personal qualities, values and attitudes, but also the system of specific economic knowledge, skills acquired in the process of appropriate training.

The study of the $\mathrm{P}(\mathrm{V}) \mathrm{E}$ students' career plans makes it possible to conclude their prime relation to the chosen training direction, and, secondly, to some extent focused on the entrepreneurship field. In a poll carried out by the Institute of vocational education and training of the National academy of educational science of Ukraine (IVET NAES of Ukraine) of 2017-2018, more than 1,000 P(V)E students from the oblast centers (Vinnytsya, Khmelnytskyi) and rural areas (Volyn region) were covered. It should be noted that in $\mathrm{P}(\mathrm{V}) \mathrm{E}$ schools of Vinnytsia and Khmelnytskyi the poll was conducted to determine the state-of-arts of the problem, that is, it was a one-time event, and in $\mathrm{P}(\mathrm{V}) \mathrm{E}$ schools of Volyn region were carried out in terms of the allUkrainian level pedagogical experiment "Organizational and pedagogical conditions of the Centre for professional careers creating and functioning in a vocational school". Accordingly, the repeated polls were aimed at revealing the dynamics of the surveyed indicators. The pedagogical experiment envisaged the efficiency verification of $\mathrm{P}(\mathrm{V}) \mathrm{E}$ students' career counselling measures. They were carried out at the Centres of professional careers (Basil, 2018). One of the results on the experimental factors influence was predicted to form students' vision of a realistic educational and professional route, primarily aimed at the horizontal career implementation.

The experimental work had a longitudinal character and encompassed: at the stated stage the I-III courses students, at the forming one - the same students (already of II-IV courses). Tables 1 and 2 summarize the results of studying the students' career plans in urban and rural areas $\mathrm{P}(\mathrm{V}) \mathrm{E}$ schools (abbr.: $\mathrm{G}$ - girls, $\mathrm{Y}$ - young people, Av - average, HEI - institutions of higher education).

The listed empirical data (table 2) obtained from the experimental work demonstrates the following: firstly, rural $\mathrm{P}(\mathrm{V}) \mathrm{E}$ schools students have a more clearly expressed vector of educational-professional route associated with work in the specialty; secondly, the

Table 1

Students' career plans for the short-term (urban P(V)E schools, \%)

\begin{tabular}{lcccccccccccc} 
Career plans & \multicolumn{3}{c}{ I course } & \multicolumn{3}{c}{ II course } & \multicolumn{3}{c}{ III course } & \multicolumn{3}{c}{ Average } \\
\hline \multicolumn{1}{l}{} & G & Y & Av & G & Y & Av & G & Y & Av & G & Y & Av \\
\hline $\begin{array}{l}\text { Work } \\
\text { in the specialty }\end{array}$ & 55,9 & 54,7 & $\mathbf{5 5 , 4}$ & 64,6 & 58,5 & $\mathbf{6 1 , 3}$ & 56,8 & 53,8 & $\mathbf{5 5 , 4}$ & 58,9 & 55,8 & $\mathbf{5 7 , 4}$ \\
\hline Change profession & 21,5 & 21,7 & $\mathbf{2 1 , 6}$ & 17,3 & 16,3 & $\mathbf{1 6 , 7}$ & 23,7 & 21,0 & $\mathbf{2 2 , 3}$ & 21,0 & 19,5 & $\mathbf{2 0 , 1}$ \\
\hline Enter HEI & 22,6 & 23,6 & $\mathbf{2 3 , 0}$ & 18,1 & 25,2 & $\mathbf{2 2 , 0}$ & 19,5 & 25,2 & $\mathbf{2 2 , 3}$ & 20,1 & 24,7 & $\mathbf{2 2 , 5}$ \\
\hline
\end{tabular}

Thus, more than half of the respondents planned to work in the speciality after leaving $\mathrm{P}(\mathrm{V}) \mathrm{E}$ schools. 
Table 2

Students' career plans for the short-term (rural P(V)E schools, \%)

\begin{tabular}{|c|c|c|c|c|c|c|c|c|c|c|c|c|}
\hline \multirow[t]{2}{*}{ Career plans } & \multicolumn{3}{|c|}{ I course } & \multicolumn{3}{|c|}{ II course } & \multicolumn{3}{|c|}{ III course } & \multicolumn{3}{|c|}{ Average } \\
\hline & $\mathbf{G}$ & $\mathbf{Y}$ & Av & $\mathbf{G}$ & & $\mathbf{G}$ & $\mathbf{Y}$ & Av & $\mathbf{G}$ & & $\mathbf{G}$ & $\mathbf{Y}$ \\
\hline \multicolumn{13}{|c|}{ Experiment stated stage } \\
\hline $\begin{array}{l}\text { Work in the } \\
\text { specialty }\end{array}$ & 73,8 & 100 & 85,4 & 84,2 & 17,7 & 58,1 & 69,2 & 76,9 & $\mathbf{7 4 , 4}$ & 76,4 & 71,4 & 73,9 \\
\hline Change profession & 4,4 & 0,0 & 2,4 & 0,0 & 15,7 & 6,4 & 23,1 & 7,7 & 12,8 & 7,2 & 7,2 & 7,2 \\
\hline Enter HEI & 21,8 & 0,0 & 12,2 & 15,8 & 66,6 & 35,5 & 7,7 & 15,4 & 12,8 & 16,4 & 21,4 & 18,9 \\
\hline \multicolumn{13}{|c|}{ Experiment forming stage } \\
\hline & \multicolumn{3}{|c|}{$\mathrm{I} \rightarrow \mathrm{II}$ course } & \multicolumn{3}{|c|}{ II $\rightarrow$ III course } & \multicolumn{3}{|c|}{$\mathrm{III} \rightarrow \mathrm{IV}$ course } & \multicolumn{3}{|c|}{ Average } \\
\hline $\begin{array}{l}\text { Work in the } \\
\text { specialty }\end{array}$ & 86,9 & 100 & 92,7 & 84,2 & 75,0 & 80,7 & 81,8 & 100 & 85,7 & 85,0 & 90,9 & 87,2 \\
\hline Change profession & 4.4 & 0,0 & 2.4 & 3,0 & 0,0 & $\mathbf{0 , 0}$ & 0,0 & 0,0 & 0,0 & 1,8 & 0,0 & 1,2 \\
\hline Enter HEI & 8,7 & 0,0 & 4,9 & 15,8 & 25,0 & 19,3 & 18,2 & 0,0 & 14,3 & 13,2 & 9,1 & 11,6 \\
\hline
\end{tabular}

Table 3

Entrepreneurship-oriented educational-professional route (\%)

\begin{tabular}{lcccccccccccc} 
& & I course & & II course & \multicolumn{4}{c}{ III course } & \multicolumn{3}{c}{ Average } \\
\hline & G & Y & Av & G & G & Y & Av & G & G & Y & Av & G \\
\hline Urban & & & & & & & & & & & & \\
P(V)E schools & 24,9 & 43,4 & $\mathbf{3 3 , 8}$ & 30,7 & 25,5 & $\mathbf{2 7 , 9}$ & 27,9 & 23,8 & $\mathbf{2 5 , 8}$ & 27,7 & 30,6 & $\mathbf{2 9 , 2}$ \\
\hline $\begin{array}{l}\text { Rural } \\
\text { P(V)E schools }\end{array}$ & 19,6 & 52,8 & $\mathbf{3 4 , 1}$ & 9,1 & 16,7 & $\mathbf{1 0 , 7}$ & 10,5 & 8,3 & $\mathbf{9 , 7}$ & 14,2 & 33,3 & $\mathbf{2 1 , 5}$ \\
\hline
\end{tabular}

desire to change the profession can be greatly neutralized by psychological and pedagogical influences from the Centres for professional careers. We also recorded a decrease from $18.9 \%$ to $11.6 \%$ the number of students planning to implement further educational and professional routs by studying in HEIs. It should be noted that according to the experiment observation results, there was a small difference in the number of students studying in urban and rural $\mathrm{P}(\mathrm{V}) \mathrm{E}$ schools and planning to continue their education in HEIs (respectively, $22.5 \%$ and $18.9 \%$, i.e. the difference in 1.2 times). After the pedagogical experiment in rural $\mathrm{P}(\mathrm{V}) \mathrm{E}$ schools, the number of students planning to continue their studies in HEIs decreased by $7.3 \%$, compared with urban $\mathrm{P}(\mathrm{V}) \mathrm{E}$ schools. The difference was 1.9 times.

In the process of the pilot study, the students' career plans for entrepreneurship were also studied. It should be noted that according to the pedagogical experiment results conducted in $\mathrm{P}(\mathrm{V}) \mathrm{E}$ schools (Volyn region), there were practically no significant changes in the number of students planning to implement educational and professional routs in the field of entrepreneurship, therefore, the data in Table 3 is based on the recording experiment results.

The results of the study have revealed several trends. First of all, the number of students planning to run a business has significantly decreased. This tendency is especially clear for rural $\mathrm{P}(\mathrm{V}) \mathrm{E}$ schools, where the number of pupils has decreased from $34.1 \%$ - in the first year and to $9.7 \%$ - in the third year, i.e. 3.5 times.

In our opinion, one of the factors is the lack of systematic economic, including entrepreneurship, training while basic secondary education acquisition. That causes formation the unsystematized, incomplete and idealized ideas on entrepreneurship of the 9 th form graduates. The survey also testified that over $60 \%$ of respondents do not have a clear idea on entrepreneurial activity, and the overwhelming majority of respondents (about $70 \%$ ) cannot define personal qualities important for entrepreneurial activity. It should be noted that such a picture was observed in 2018 (Tkachenko, 2018), ten and twenty five years ago (Zakatnov, 2007, Zakatnov and Tymenko, 1993, respectively).

Therefore, in the process of general vocational, professional-theoretical and vocational-practical training in $\mathrm{P}(\mathrm{V}) \mathrm{E}$ schools the 9th form graduates should acquire systematic knowledge on entrepreneurship to form the an objective vision of the activity. The tasks of the Centre for professional careers included the realistic "I-vision" formation of students. These factors help students to objectively assess their opportunities in related entrepreneurial activity and make the well- 
considered decision on the future professional activities vector - to be hired or self-employed in terms of entrepreneurial activities.

At the same time, world experience shows that entrepreneurial activity is one of efficient means to increase the national economies productivity. That demands the systematic students training and preparation for entrepreneurial activity. In this case, there is a logical question: what should be the result of such training? The researchers of this problem (V. Drzhak, N. Pasichnyk, O. Topol and others), since the 1980's, operated the following categories: "readiness to choose business", "readiness for entrepreneurial activity", "interest in entrepreneurial activity", etc. Recently the national pedagogy has placed the main emphasis on the category of "competence". That determines the relevance to consider $\mathrm{P}(\mathrm{V}) \mathrm{E}$ schools students training right in the competent-based approach context (Radkevych, 2012, s. 10-11).

On January 17, 2018, the European Parliament and the Council of the European Union endorsed the Framework program to update the key competences for lifelong learning (European Union, 2018), in particular "employment", "personal capacity building" etc. This document contains the list of competencies somewhat different from the same list of the European Parliament and European Council Recommendations dated 18 December 2006 (European Parliament and Council of the European Union, 2006). If in the Recommendations of 2006 there were Communication in the mother tongue, Communication in foreign languages, Mathematical competence and basic competences in science and technology, Digital competence, Learning to learn, Social and civic competences, Sense of initiative and entrepreneurship, Cultural awareness and expression), then the list adopted in the Recommendations of 2018 consists of the following competences: Literacy competence, Languages competency, Mathematical competence and competence in science, technology and engineering, Digital competence), Personal, social and learning competence, Civic competence, Entrepreneurship competence, Cultural awareness and expression competence. This document defines the concept of "entrepreneurship" is as the ability to plan and manage projects that have cultural, social or commercial value, that is, it is not limited to economic activities only and differs from the interpretation of this definition in the legislation of Ukraine.

The analysis of psychological and pedagogical literature shows that some domestic researchers' attention is paid to the problem of entrepreneurial competence formation; however, it is mainly devoted to certain aspects of this process. In our view, solving the problem of $\mathrm{P}(\mathrm{V}) \mathrm{E}$ students training requires a system designing and implementation taking into account external and internal factors impact, its phasing, linking the economic and entrepreneurial training of the youth, pedagogical potential in general education, general vocational, professional and practical training, interaction with employers, etc.; representing theoretical basis for system functioning (purpose and subjects, theoretical foundations and principles of training for entrepreneur activities, professional and career theory of personality development, etc.). The system-forming element of that pedagogical system is its purpose. The analysis of modern competence-based $\mathrm{P}(\mathrm{V}) \mathrm{E}$ standards make possible to conclude that the entrepreneurial competence is a component of $\mathrm{P}(\mathrm{V}) \mathrm{E}$ schools graduates' general professional competence. Thus, the purpose of $\mathrm{P}(\mathrm{V}) \mathrm{E}$ schools students training system is the entrepreneurial competence formation.

Conclusions. Formation of students' entrepreneurial competence is a crucial sociopedagogical problem, one of the ways to improve human capital quality, ensuring $\mathrm{P}(\mathrm{V}) \mathrm{E}$ schools graduates' professional mobility and competitiveness. This way of solving this problem is a pedagogical system designing and implementation providing the entrepreneurial activity to $\mathrm{P}(\mathrm{V}) \mathrm{E}$ schools students. The purpose of the system is to form the integral personal de novo synthesis for $\mathrm{P}(\mathrm{V}) \mathrm{E}$ schools students - the entrepreneurial competence. The solution of this problem requires the integrated study aimed at revealing the theoretical basis for the system establishment, internal and external factors interconnection and interdependence affecting students training for entrepreneurial activity, specifying the essence of "P(V)E schools students' entrepreneurial competence", studying the structure of the competence, indicators and formation criteria, functioning methodological and technological support, the an efficiency assessing algorithm development for the system of that kind realisation.

\section{List of references}

Базиль, Л.О., 2018. Концепція функціонування центрів професійної кар'єри у закладах освіти. В: Підготовка майстра виробничого навчання, викладача професійного навчання до впровадження в освітній процес інноваиійних технологій: Матеріали II Всеукраӥнського науково-методичного семінару. Глухів, Україна, 1 листопада 2018 року. Глухів: б.в., с. 11-16.

Закатнов, Д.О. та Тименко М.П., 1993. Готувати сучасних підприємців. Рідна школа, 3, с. 20-22.

Закатнов, Д.О., 2008. Організаційно-педагогічне забезпечення підготовки учнівської молоді до побудови кар'єри. Теоретико-методичні проблеми виховання дітей та учнівської молоді: зб. наук. пр., 10, кн.II, с. 373-381. 
Радкевич, В. О., 2012. Компетентнісний підхід до забезпечення якості професійної освіти і навчання. В: Науково-методичне забезпечення професійної освіти і навчання: матеріали Всеукр. (звіт.) наук.-практ. конф. (23 березня 2012 р., м. Київ ), Київ: Ін-т проф.-техн. освіти НАПН України. Вип. 1, с. 9-15.

Ткаченко, В.М., 2018. Формування підприємницької компетентності майбутніх фахівців ресторанного господарства у професійно-технічних навчальних закладах. Кандидат наук. Інститут професійно-технічної освіти НАПН України.

European Parliament and the Council of the European Union, 2006. Recommendation of the European Parliament and of the Council of 18 December 2006 on key competences for lifelong learning (2006/962/EC), [online] Available at: $<$ https://eur-lex.europa.eu/legal-content/EN/TXT/?uri=celex\%3A32006H0962>

European Union, 2018. Council Recommendation of 22 May 2018 on key competences for lifelong learning, [online] Available at: <https://ec.europa.eu/education/education-in-the-eu/council-recommendation-on-key-competences-forlifelong-learning_en> [Accessed 10 May 2019].

UNESCO, 2016. Action Plan for the Implementation of the Strategy for Technical and Vocational Education and Training (TVET) (2016-2021), [online] Available at: <https://unesdoc.unesco.org/ark:/48223/pf0000245543> [Accessed 10 May 2019].

\section{Translated \& Transliterated}

Bazyl, L.O., 2018. Kontseptsiia funktsionuvannia tsentriv profesiinoi kariery u zakladakh osvity [The Concept of Centre for professional careers functioning in educational institutions]. V: Pidhotovka maistra vyrobnychoho navchannia, vykladacha profesiinoho navchannia do vprovadzhennia $v$ osvitnii protses innovatsiinykh tekhnolohii: Materialy II Vseukrainskoho naukovo-metodychnoho seminaru. Hlukhiv, Ukraina, 1 lystopada 2018 roku. Hlukhiv [Training the master of industrial training for introducing innovative technologies in the education process]: b.v., s. 11-16, [in Ukrainian].

Zakatnov, D.O. ta Tymenko M.P., 1993. Hotuvaty suchasnykh pidpryiemtsiv[Train the modern entrepreneurs]. Ridna shkola [Native school], 3, s. 20-22, [in Ukrainian].

Zakatnov, D.O., 2008. Orhanizatsiino-pedahohichne zabezpechennia pidhotovky uchnivskoi molodi do pobudovy kariery [Organisation-pedagogical support of the youth training for choosing the career]. Teoretyko-metodychni problemy vykhovannia ditei ta uchnivskoi molodi: zb. nauk. pr. [Theoretical-methodological problems of children and the youth training]. Vyp. 10. Kn. II. Kamianets-Podilskyi, s. 373-381, [in Ukrainian].

Radkevych, V. O., 2012. Kompetentnisnyi pidkhid do zabezpechennia yakosti profesiinoi osvity $i$ navchannia [Competence approach to ensuring the quality of vocational education and training.]. V: Naukovo-metodychne zabezpechennia profesiinoi osvity i navchannia [Scientific and methodical provision of vocational education and training]: materialy Vseukr. (zvit.) naukr.-prakt. konf. (23 bereznia 2012 r., m. Kyiv ), Kyiv: In-t prof.-tekhn. osvity NAPN Ukrainy. Vyp. 1, s. 9-15, [in Ukrainian].

Tkachenko, V.M., 2018. Formuvannia pidpryiemnytskoi kompetentnosti maibutnikh fakhivtsiv restorannoho hospodarstva u profesiino-tekhnichnykh navchalnykh zakladakh [Entrepreneurship competence forming for future hospitality sector specialists in vocational education and training schools]. Kandydat nauk. Instytut profesiino-tekhnichnoi osvity NAPN Ukrainy, [in Ukrainian].

European Parliament and the Council of the European Union, 2006. Recommendation of the European Parliament and of the Council of 18 December 2006 on key competences for lifelong learning (2006/962/EC), [online] Available at: $<\mathrm{https}$ ://eur-lex.europa.eu/legal-content/EN/TXT/?uri=celex\%3A32006H0962> [Accessed 08 May 2019], [in English].

European Union, 2018. Council Recommendation of 22 May 2018 on key competences for lifelong learning, [online] Available at: https://ec.europa.eu/education/education-in-the-eu/council-recommendation-on-key-competences-for-lifelonglearning_en [Accessed 10 May 2019], [in English].

UNESKO, 2016. Action Plan for the Implementation of the Strategy for Technical and Vocational Education and Training (TVET) (2016-2021), [online] Available at: https://unesdoc.unesco.org/ark:/48223/pf0000245543 [Accessed 10 May 2019], [in English].

\section{Підприсмницька діяльність як напрям освітньо-професійних траєкторій учнів закладів професійної (професійно-технічної) освіти}

\section{Дмитро Закатнов,}

кандидат педагогічних наук, старший науковий співробітник, завідувач лабораторії професійної кар'єри Інституту професійно-технічної освіти НАПН України

Реферат. У статті висвітлено стан проблеми підготовки учнів закладів професійної (професійно-технічної) освіти (далі: ЗП(ПТ)О) до вибору підприємницької діяльності як напряму розвитку професійної кар'єри. Виявлено, що зміст підприємницької діяльності в нормативно-правовому полі України обмежується господарською діяльністю, спрямованою на досягнення економічних і соціальних результатів та одержання прибутку, на відміну від ії змістовного наповнення в країнах СС, де підприємництво визначається як уміння планувати й управляти проектами, що 
мають культурну, соціальну або комерційну цінність. Аналіз емпіричних результатів пілотного дослідження та експериментальної роботи Інституту професійно-технічної освіти НАПН України (далі: ІПТО НАПН України) засвідчив, що підприємницька діяльність розглядається учнями ЗП(ПТ)О як перспективний напрям реалізації подальшої освітньо-професійної траєкторії, хоча існує певна відмінність у відносних показниках орієнтації на таку діяльність в учнів ЗП(ПТ)О, розташованих у містах та сільській місцевості. Однак уявлення учнів стосовно підприємницької діяльності носять переважно абстрактний характер, а підготовка до підприємницької діяльності в ЗП(ПТ)О здійснюється переважно за іiі окремими аспектами. Соціально-економічна значущість підприємницької діяльності та іiі привабливість для молоді як перспективного вектора реалізації освітньо-професійних траєкторій зумовлюють доцільність проектування та реалізації в освітньому процесі ЗП(ПТ)О педагогічної системи підготовки учнів у галузі підприємницької діяльності.

Відповідно до сучасної освітньої парадигми, в основу такої системи доцільно покласти компетентнісний підхід, а метою ï функціонування визначити формування в учнів ЗП(ПТ)О підприємницької компетентності як інтегрального особистісного стійкого новоутворення. Визначено основні вимоги стосовно структури такої системи та окреслено коло проблем, розв'язання яких сприятиме підвищенню ефективності підготовки учнів ЗП(ПТ) освіти до підприємницької діяльності.

Ключові слова: підприємецьь, підприємницька діяльність, система підготовки до підприємницької діяльності, освітньо-професійна траєкторія, професійна (професійно-технічна) освіта. 